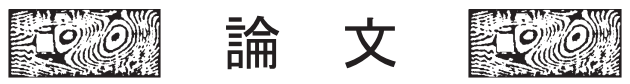

\title{
非定常空気力に基づく大スパン屋根の空力安定性評価 \\ Discussion of Aerodynamic Stability of Long-Span Roofs based on Unsteady Aerodynamic Forces
}

\author{
高舘祐貴*1 \\ 植松 康*2 \\ Yuki TAKADATE \\ Yasushi UEMATSU
}

\section{SUMMARY}

Aerodynamic stability of long-span roofs is investigated on the basis of computational fluid dynamics (CFD) with a large eddy simulation (LES). A forced vibration test is performed to obtain the unsteady aerodynamic forces for the first anti-symmetric mode. The CFD simulation method is first verified by comparing the results with the previous experimental results. Then, the unsteady aerodynamic forces, represented by the aerodynamic stiffness and damping coefficients, at the location of the anti-nodes of vibration as well as on the whole roof are computed for various wind velocities, vibration frequencies, and vibration amplitudes. The resonant effect and aerodynamic stability are discussed based on the results. Finally, the critical wind velocity that induces the aerodynamically unstable vibration is provided on the basis of the relation between the mass damping parameter and the non-dimensional wind velocity.

key words: Long-span roof, aerodynamic stability, CFD simulation, forced vibrating test, unsteady aerodynamic

$$
\text { forces, mass damping parameter }
$$

\section{1.はじめに}

近年, 新たな構造材料や工法の開発, 解析技術の発展に よって，軽量かつ大スパンの膜屋根を用いた構造物の建 設が可能となった。このような建築物では一般に剛性が 低いため, 設計時には風荷重が支配的となる。特に, 大ス パン屋根では風による変形が生じやすく, 接近流の乱れ や流れの剥離に伴う変動空気力だけでなく，屋根の振動
に伴う付加的な空気力(非定常空気力)も生じるため，屋根 の応答は非常に複雑なものとなる。我が国でこれまでに 建設された大空間構造物では, 通常, 自重や気流の乱れに よる風力に比べて空力剛性や空力減衰といった非定常空 気力の効果は小さく，これらの効果を考慮する必要性は ほとんどなかった。しかし, 屋根の大スパン化や軽量化に よって，非定常空気力の効果が相対的に大きくなること

\footnotetext{
* 1 国立研究開発法人建築研究所 構造研究グループ 研究員 takadate@kenken.go.jp Researcher, Department of Structural Engineering, Building Research Institute

* 2 独立行政法人国立高等専門学校機構 秋田工業高等専門学校 校長 President, National Institute of Technology (KOSEN), Akita College

(原稿受理年月日：2019 年 10 月 3 日，採用決定年月日：2020 年 1 月 21 日)
} 
から，風による構造物の空力不安定振動の発生が懸念さ れる。

空力安定性を評価するための代表的な実験手法には自 由振動法と強制加振法がある。自由振動法を用いた大ス パン屋根の空力安定性に関する研究について, Uematsu and Uchiyama ${ }^{1}$ は押さえ材を鉛直ばねで置き換えた一方向 吊屋根模型を用いて一様流中で実験を行い，屋根の動的 応答や空力不安定振動の発生条件を評価した。松本 ${ }^{2}$ は, 一様流中の吊屋根に対して空力弾性模型を用いた風洞実 験を行うことで, 自励振動の無次元発振風速を示した。三 宅ら ${ }^{3)}$ は, 一様流と境界層乱流を用いた風洞実験に基づき, 大スパン屋根の励振特性を明らかにした。

強制加振法を用いた代表的な研究として，Daw and Davenport $^{4}$ は半円筒形膜構造物を対象とし, 逆対称一次モ 一ドの強制加振実験より得られた非定常空気力を用いて 構造物の動的応答を評価した。大熊ら ${ }^{5,}$, 6),7) は様々な形状 を有する大スパン屋根に作用する平均並びに変動風圧の 特性を調べた。また, 大スパン陸屋根については, 強制加 振装置を用いて屋根面を逆対称一次モードで強制的に加 振することで，振動する屋根面に作用する変動風圧の特 性を明らかにするとともに，振動に伴う非定常空気力の 速度比例成分と変位比例成分の特性に基づき, 屋根の空 力安定性について考察した。

近年では, 数值流体解析による検討も行われている。例 えば, 杉山ら ${ }^{8)}$ は, 一様流中の陸屋根に対して強制加振解 析ならびに自由振動解析を行うことで，屋根に作用する 非定常空気力および屋根の動的応答特性を把握し, 空力 不安定振動の基本的な性状を示した。Ding and Uematsu ${ }^{9}$ ) は円弧屋根を対象とした風洞実験並びに数值流体解析に よって屋根面に作用する風圧ならびに非定常空気力を評 価し, 非定常空気力の影響を考慮した周波数応答関数を 用いることで屋根の動的応答特性を検討した。最近, $\mathrm{Li}^{10)}$ らは大熊ら ${ }^{7)}$ 並びに Ding and Uematsu ${ }^{9}$ の風洞実験を模擬 した数值流体解析を行い，スペクトルモーダル解析に基 づき屋根の動的応答を評価している。

このように大スパン屋根の風による動的応答や空力安 定性に関する研究については，これまで様々な検討が行 われているものの, 自由振動法では模型の相似則を満た すことが，強制振動法では実験装置の作製が困難である ことから，様々な形状を有する大スパン屋根の空力安定 性を包括的に評価した研究は為されていない。また，いず れの手法においても屋根の動的応答に関する検討は行わ れているが, 多くは一様流や一様乱流によるものであり, 境界層乱流中での振動性状や空力不安定振動の発生条件
については必ずしも明らかになっていない。

本研究では, 数值流体解析を用いた強制加振実験(数值 実験)に基づき，代表的な屋根形状(陸屋根，円弧屋根，吊 屋根)を有する大スパン屋根の空力不安定振動の発生条件 を明らかにすることを目的とする。まず, 本研究で用いる 強制加振実験法について, 得られた風圧分布を既往の実 験結果と比較することでその妥当性を示す。次に, 非定常 空気力を空力剛性および空力減衰として評価することで, 非定常空気力が屋根の応答に及ぼす影響や風速の増加に 伴う非定常空気力の変化を明らかにする。最後に, 大スパ ン屋根の空力不安定振動の発生風速を明らかにするため に, 構造減衰と空力減衰の関係式から質量減衰パラメー 夕と無次元風速の関係式を導き, 各屋根形状に対する空 力不安定振動の発生条件を示す。

\section{2. 数值流体解析の概要}

2. 1 対象とする屋根形状

本研究では, わが国で建設された大空間構造物に対し て行われた調查(例えば，植松ら ${ }^{11}$ ) に基づき，その代表的 な屋根形状として, 陸屋根, 円弧屋根, 吊屋根の 3 種類 を対象とする。

図 1 に対象とする建築物とそのパラメータを示す。風 方向のスパンを $L$, 風直交方向の幅を $B$, 軒高を $H$ で表 す。実スケールでは $L=120 \mathrm{~m}, H=20 \mathrm{~m}$ とする。円弧屋 根や吊屋根には様々なライズ・スパン比 $(r / L)$ あるいはサ グ・スパン $(d / L)$ 比が存在するが, 本研究では代表的な值と して, 円弧屋根では $r / L=0.1$ と 0.2 , 吊屋根では $d / L=0.05$ と 0.1 の 2 種類とする。数值流体解析は風洞実験を模擬 した縮小モデルでの解析とし, 解析モデルの幾何学的縮 尺率を $1 / 400$ と仮定する。また, 本研究では一方向屋根を 対象とし, 屋根に作用寸る非定常空気力などは屋根中心 線上の 2 次元的な流れに基づいて評価する。

2. 2 解析手法とメッシュ分割

数值流体解析で用いる計算コードは ANSYS Fluent (ver. 17.2)であり, 乱流モデルには LES(Large Eddy Simulation) を用いる。このとき, 支配方程式は次式に示される連続式

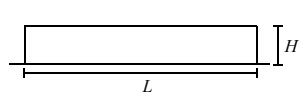

(a) 陸屋根

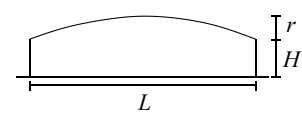

(b) 円弧屋根

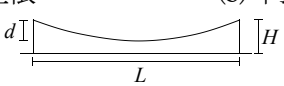

(c) 吊屋根

図 1 対称とする屋根形状と記号の定義

Fig. 1 Roof shapes and notation 


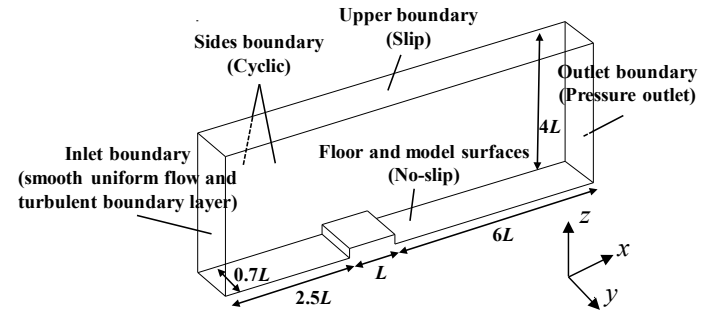

図 2 解析領域

Fig. 2 Computational domain

表 1 解析条件

Table. 1 Computational condition

\begin{tabular}{ll}
\hline 計算領域 & $9.5 L(x) \times 0.7 L(y) \times 2.5 L(z)$ \\
\hline 流入境界 & 一様流, 境界層乱流 \\
\hline 上面境界 & Slip 条件 \\
\hline 左右境界 & Cyclic 条件 \\
\hline 床面・モデル表面 & no-slip 条件 \\
\hline 総メッシュ数 & 620,000 \\
\hline 空間項の離散化 & 2 次精度中心差分 \\
\hline 時間項の離散化 & 2 次精度陰解法 \\
\hline 数值解法 & PISO 法 \\
\hline 無次元時間刻み & $4.0 \times 10^{-3}$ \\
\hline 解析時間 & 6 秒 1 セット \\
\hline
\end{tabular}

と Navier-Stokes 方程式(運動方程式)である。

$$
\begin{gathered}
\frac{\partial \bar{u}_{i}}{\partial x_{i}}=0 \\
\frac{\partial \bar{u}_{i}}{\partial t}+\frac{\partial \bar{u}_{i} \bar{u}_{j}}{\partial x_{j}}=-\frac{1}{\rho} \frac{\partial \bar{p}}{\partial x_{i}}+\frac{\partial}{\partial x_{j}}\left(v \frac{\partial \bar{u}_{i}}{\partial x_{j}}\right)-\frac{\partial \tau_{i j}}{\partial x_{j}}
\end{gathered}
$$

ここで, $i=1 \sim 3, j=1 \sim 3$ であり, $x_{i}$ は空間座標の 3 成分 (図 2 の $x, y, z$ ), $u_{i}$ は風速の $x_{i}$ 成分, $p$ は圧力, $v$ は動粘性 係数, $\tau_{i j}$ はサブグリッドスケール(SGS)応力を示す。また，

一は空間フィルタを示す。サブグリッドスケール(SGS)モ デルにはWALE モデル(Wall-Adapting Local-Eddy-viscosity model $)^{12}$ を用いる。モデル定数は Nicord and Ducros ${ }^{12}$ によ る検討結果と本研究で独自に実施したパラメトリックス タディに基づき $C_{W}=0.325$ とする。空間項の離散化には 2 次精度中心差分を用い，時間項の離散化には 2 次精度陰 解法を用いる。図 2 に解析領域と境界条件，表 1 に主な 解析条件を示す。屋根に作用寸る風圧や非定常空気力な どについては，屋根の中心線を含む鉛直面内の 2 次元的 な流れに着目するが，実際には乱流エネルギーの輸送な ど 3 次元的な流れが発生するため, 解析は左右の壁面を 周期境界とした 3 次元空間に対して行う。メッシュ分割 の妥当性については文献 13)〜15)を参照されたい。解析 においては様々な無次元風速に対する検討を行うために, 軒高風速 $U_{\mathrm{H}}$ を $6 \sim 15 \mathrm{~m} / \mathrm{s}$ の範囲で変化させる。解析時間

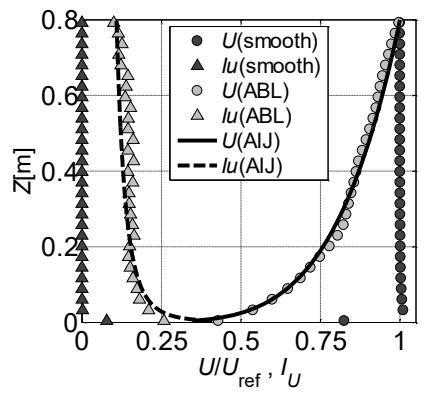

（a）流入風のプロファイル

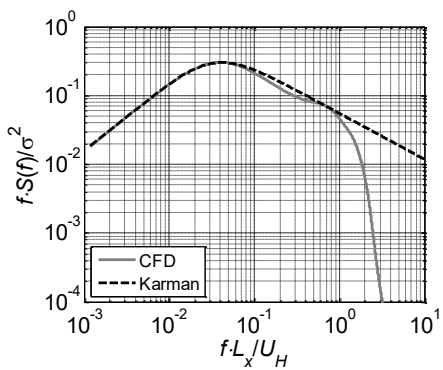

(b) 変動風速のパワースペクトル密度 $(z=0.05 \mathrm{~m})$ 図 3 モデル中心位置における流入変動風の特性

Fig. 3 Characteristics of approach flow at the center of the model without model

は実スケールで 10 分間とし, 軒高風速に応じて時間刻み $\Delta t$ を変化させる。なお，解析における無次元時間刻み $\Delta t^{*}\left(=\Delta t U_{\mathrm{H}} / L\right)$ は $4.0 \times 10^{-3}$ である。

\section{3 流入境界条件}

流入境界条件には，気流の乱れが応答性状に及ぼす影 響を把握するために，一椂流と境界層乱流の 2 種類を用 いる。LES を用いた数值流体解析では, 時々刻々と変化 する流入変動風の生成がしばしば課題となる。本研究で は, 平均風速 $\bar{U}$, 乱流エネルギー $k$ 並びに消散率 $\varepsilon$ 与え,

ANSYS Fluent(Ver. 17.2) に実装されている Spectral Synthesizer ${ }^{16}$ を用いて，人工的に流入変動風を作成する。 人工的に生成した流入変動風は, Navier-Stokes 方程式を 必ずしも満たしていないため，吹送すると乱れ強さが小 さくなるが，本研究では流入境界で与える各パラメータ をチューニングし，ある程度十分な吹送距離を確保する ことで，モデル中心位置でのプロファイルが建築物荷重 指針・同解説 ${ }^{17}$ ( 以下，「荷重指針」と呼ぶ)の地表面粗度 区分而に概ね相当する気流(べき指数 $\alpha=0.20$ ) となるように 生成した。図 3 にモデル中心位置における平均風速およ び乱れ強さの鉛直プロファイルと変動風速のパワースペ クトルを示寸。図 3(a)には，一様流(smooth)，境界層乱流 (TBL)，荷重指針に規定される地表面粗度区分III $の$ 值(AIJ) が示されている。これより, 生成された境界層乱流のプロ ファイルは地表面粗度区分而の值とよく一致しているこ 


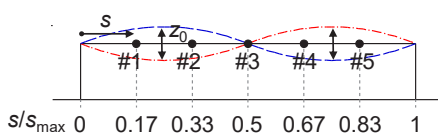

(a) 陸屋根

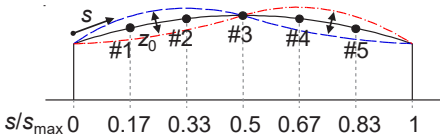

(b) 円弧屋根

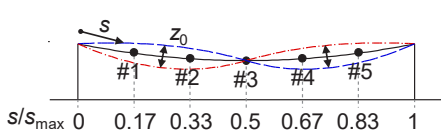

(c) 吊屋根

図 4 強制加振時の変形性状(逆対称一次モード)

Fig. 4 Deforming shape in the forced vibration test (first anti-symmetric mode)

とが分かる。また, 生成された流入変動風のパワースペク トル密度(図 3(b))に着目すると, 高振動数領域でパワーは 減少しているが, 荷重評価で重要となる $f \cdot L_{x} / U_{H}<1.0$ にお けるパワースペクトル密度は, 荷重指針で用いられてい る Karman 型とよく一致している。

\section{2 . 3 屋根面の強制加振}

本研究では, 内部容積の変化がなく, 内圧が屋根の振動 の抵抗とならない振動モードであり, 既往の風洞実験 ${ }^{1)}$

2), 4), 7), 9) でも検討されている逆対称一次モードを対象とす る。図 4 にモード形を示す。一般に， $k$ 次モードにおける 屋根面の変位 $z_{k}(s, t)$ は次式で表される。

$$
\begin{aligned}
& z_{k}(s, t)=x_{z}(t) \phi_{k}(s) \\
& \phi_{k}(s)=\sin \left(k \pi \frac{s}{s_{\text {max }}}\right)
\end{aligned}
$$

- $f_{\mathrm{m}}{ }^{*}=0\left(\mathrm{WT}^{6)}\right) \quad \Delta f_{\mathrm{m}}{ }^{*}=0\left(\mathrm{CFD}^{10)}\right) \quad-f_{\mathrm{m}}{ }^{*}=0(\mathrm{CFD})$ - $f_{\mathrm{m}}^{*}=0.5\left(\mathrm{WT}^{6}\right) \Delta f_{\mathrm{m}}{ }^{*}=0.5\left(\mathrm{CFD}^{10}\right)-f_{\mathrm{m}}{ }^{*}=0.5(\mathrm{CFD})$

$\left.\circ f_{\mathrm{m}}{ }^{*}=1.5\left(\mathrm{WT}^{6}\right)\right) \Delta f_{\mathrm{m}}{ }^{*}=1.5\left(\mathrm{CFD}^{10)}\right)-f_{\mathrm{m}}{ }^{*}=1.5(\mathrm{CFD})$

$\circ f_{\mathrm{m}}{ }^{*}=2.5\left(\mathrm{WT}^{6}\right) \Delta f_{\mathrm{m}}{ }^{*}=2.5\left(\mathrm{CFD}^{10)}\right)-f_{\mathrm{m}}{ }^{*}=2.5(\mathrm{CFD})$

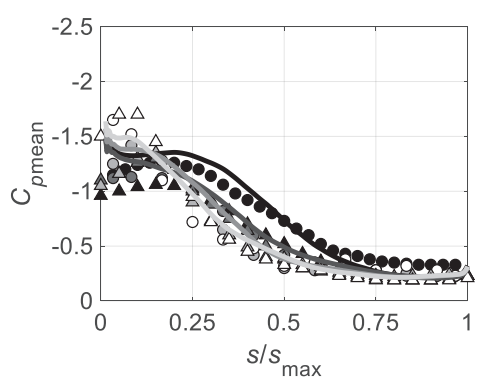

(a) 平均風圧係数分布

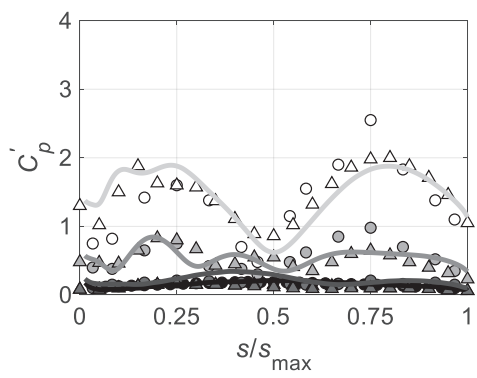

(b) RMS 変動風圧係数分布

図 5 振動する陸屋根に作用する風圧係数分布

Fig. 5 Distributions of wind pressure coefficients on the vibrating flat roof

$$
x_{z}(t)=z_{0} \sin \left(2 \pi f_{m} t\right)
$$

ここで， $\phi_{k}$ はモード形， $x_{z}$ は一般化変位， $s$ はモデルの風 上端部から屋根に沿った座標, $s_{\max }$ は $s$ の最大值, $z_{0}$ は加 振振幅, $f_{m}$ は加振振動数を示す。なお, 屋根の加振方向は 初期形状に対して法線方向とする。以下では, 特に断りが ない限り, $k=2$ の逆対称一次モ一ドを対象とし, 添え字の $k$ は省略する。屋根の振動に伴うメッシュの変形には Hooke の法則に基づく Spring smoothing 法 ${ }^{16)}$ を用いる。加 振振幅と加振振動数はそれぞれ無次元加振振幅 $z_{0}{ }^{*}\left(=z_{0} / L\right)$ と無次元加振振動数 $f_{m}{ }^{*}\left(=f_{m} L / U_{\mathrm{H}}\right)$ として表す。強制加振時 の無次元加振振幅 $z_{0}^{*}$ は $3.3 \times 10^{-3}, 1.0 \times 10^{-2}, 2.0 \times 10^{-2}$ の 3 段階で変化させる。加振振動数 $f_{m}$ はモデルスケールで 0 〜 $60 \mathrm{~Hz}$ の範囲は $10 \mathrm{~Hz}$ 刻みで，60〜160 Hzの範囲は 20 $\mathrm{Hz}$ 刻みで変化させる。つまり, 無次元加振振動数 $f_{m}{ }^{*}$ を 0 〜 の範囲で多段階に変化させる。

2. 4 解析の妥当性の検証

既往の研究 6,9),10)では, 風洞実験および数值流体解析に おいて強制加振された屋根に作用する風圧分布が示され ている。ここでは, まず本研究で用いる強制加振解析法の 妥当性を検証するために, 強制加振屋根面の風圧分布を 既往の風洞実験結果と比較する。なお, 既往の風洞実験お よび数值流体解析において，陸屋根では一様乱流(乱れ強 さ 7\%)中で, 円弧屋根では境界層乱流中で検討が行われ ているため, 本解析でも同様の解析条件を用いる。なお, 円弧屋根のライズ・スパン比は $r / L=0.15$ である。

図 5 に陸屋根における平均風圧係数 $C_{p \text { mean }}$ および RMS 変動風圧係数 $C_{p}$ 'の分布を示す。凡例中の值は無次元振動 数 $f^{*}$ を表し, 本解析の結果と比較するために, 大熊ら ${ }^{6)} の$ 風洞実験 $(\mathrm{WT})$ と $\mathrm{Li} ら^{10)}$ による数值流体解析(CFD)の結果 をプロットしている。陸屋根の場合, 平均風圧係数は加振 振動数が大きくなるにつれて風上端部近傍での負圧が大 きくなるとともに，風上側領域 $\left(0.1<s / s_{\max }<0.4\right)$ において $C_{p \text { mean }}<-1.0$ であるような大きな負圧の作用する範囲が狭 くなっている。 RMS 変動風圧係数分布では, 逆対称一次 モードの腹の位置 $\left(s / s_{\max }=0.25,0.75\right)$ でその大きさが大きく なるが，節の位置 $\left(s / s_{\max }=0.5\right)$ では小さくなっている。困 6 に円弧屋根における平均風圧係数および RMS 変動風圧 

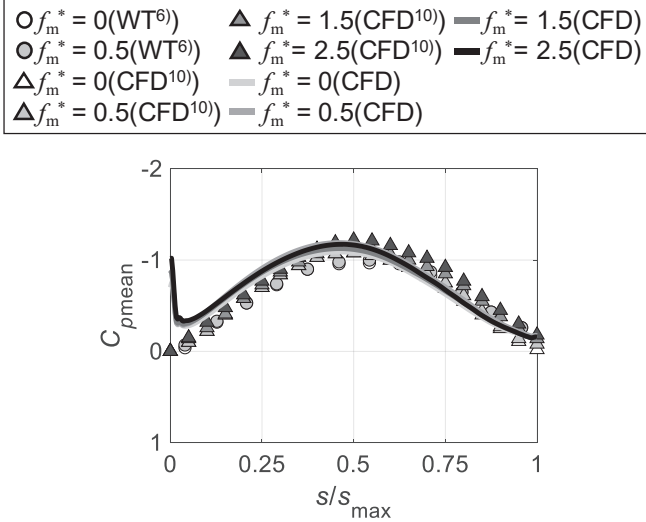

(a) 平均風圧係数分布

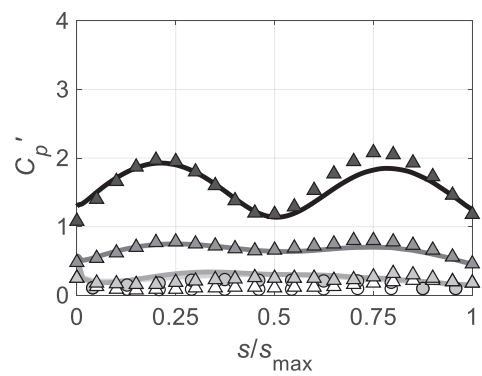

(b) RMS 変動風圧係数分布

図 6 振動する円弧屋根に作用する風圧係数分布

Fig. 6 Distributions of wind pressure coefficients on the vibrating cylindrical roof

係数分布を示す。戝には, Ding and Uematsu' ${ }^{9)}$ にる風洞実 験(WT) と $\mathrm{Li} ら^{10)}$ による数值流体解析(CFD)の結果も示さ れている。円弧屋根の場合, 屋根の振動が平均風圧係数分 布に及ぼす影響は非常に小さく, 加振振動数によらずほ ぼ同様の分布となっている。これは陸屋根とは異なり, 時 間平均的には屋根に沿った流れが支配的になることが原 因と考えられる。 RMS 変動風圧係数の值は, 陸屋根と同 様, 振動モードの腹の位置において大きく, 節の位置にお いてやや小さい。いずれの結果についても, 本研究におけ る数值流体解析に基づく強制振動解析の結果は, 既往の 風洞実験および数值流体解析の結果とよく一致している。 以上の結果より，本論文で用いた数值流体解析は妥当で あると判断できる。

3. 非定常空気力による空力安定性の評価

3. 1 非定常空気力の定義

屋根の空力安定性を評価するために，屋根全体に作用 する風力に基づきモーダル風力として表された非定常空 気力を考える。逆対称一次モードで振動する振動屋根面 の運動方程式は次式で表される。

$$
\begin{gathered}
M_{S} \ddot{x}_{z}+C_{S} \dot{x}_{z}+K_{S} x_{z}=F_{k}\left(t, x_{z}, \dot{x}_{z}, \ddot{x}_{z}, \ldots\right) \\
F_{k}\left(t, x_{z}, \dot{x}_{z}, \ddot{x}_{z}, \ldots\right) \\
\quad=F_{W}(t)+F_{T}(t)+F_{A}\left(t, x_{z}, \dot{x}_{z}, \ddot{x}_{z}, \ldots\right)
\end{gathered}
$$

ここで, $M_{S}$ は一般化質量, $C_{S}$ は一般化減衰, $K_{S}$ は一般化 岡性, $F_{W}$ は流れの剥離に伴う変動風力, $F_{T}$ は接近流の乱 れに伴う変動風力, $F_{A}$ は非定常空気力を表す。なお, $k$ 次 モードで振動する屋根に作用する一般化風力 $F_{k}$ は屋根に 作用する外圧 $P_{\mathrm{e}}$ とモード形状 $\phi_{k}$ を用いて次式で表される。

$$
F_{k}(t)=\int_{0}^{s_{\max }} P_{\mathrm{e}}(s, t) \phi_{k}(s) d s
$$

ここでは, 屋根中心線上の 2 次元的な流れ場に基づいて 評価を行うため, 屋根の幅 $B$ は単位幅 $\left(B_{\mathrm{u}}=1\right)$ とする。ま た, 振動モードとして内部容積の大きさが変化しない逆 対称一次モード $(k=2)$ を対象とするため, 屋根に作用する 内圧は 0 と仮定する。式(6)の非定常空気力 $F_{A}$ は変位比例 成分と速度比例成分の和として近似的に次式のように表 すことができる。

$$
F_{A}\left(t, x_{z}, \dot{x}_{z}, \ddot{x}_{z}, \ldots\right)=C_{a} \dot{x}_{z}+K_{a} x_{z}
$$

ここで， $C_{a}$ は一般化空力減衰， $K_{a}$ は一般化空力剛性を表 す。これより式(6)は近似的に次式のように表される。

$M_{S} \ddot{x}_{z}+\left(C_{S}-C_{a}\right) \dot{x}_{z}+\left(K_{S}-K_{a}\right) x_{z}=F_{T}(t)+F_{W}(t)$

風と屋根の連成を考える場合, 屋根の振動に伴って生 じる非定常空気力によって屋根に作用する風圧は非常に 複雑なものとなる。特に, 軽量かつ岡性が低い大スパン屋 根では屋根の変形・振動が大きくなるだけでなく, 一般に 構造減衰も小さいことから非定常空気力は構造物の応答 に大きく影響すると考えられる。例えば，式(10)において $C_{\mathrm{a}}>0$ または $K_{\mathrm{a}}>0$ の時, 空力減衰や空力剛性によって系 全体の減衰や剛性が減少するため, 屋根の振動が大きく なる。特に, $\left(C_{\mathrm{S}}-C_{\mathrm{a}}\right)<0$ となると, 系全体の減衰が負と なるため発散的な振動が発生する。一方, $C_{\mathrm{a}}<0$ または $K_{\mathrm{a}}$ $<0$ の時, 系全体の減衰や岡性が増大寸るため, 振動は空 力的に安定化する。したがって,この空力減衰や空力剛性 で表される非定常空気力の特性を把握することが屋根面 の動的応答や空力安定性を評価する上で重要となる。

逆対称一次モードで強制加振された屋根に作用する非 定常空気力 $F_{A}$ は一般化風力 $F$ をフーリエ級数展開するこ とで，モードの直交関係より変位比例成分と速度比例成 分を以下のように独立に取り出すことができる。

$$
\begin{gathered}
F_{A}=F_{R} \sin 2 \pi f_{m} t+F_{I} \cos 2 \pi f_{m} t \\
F_{R}=\frac{1}{T} \int_{-T}^{T} F(t) \sin \left(2 \pi f_{m} t\right) d t \\
F_{I}=\frac{1}{T} \int_{-T}^{T} F(t) \cos \left(2 \pi f_{m} t\right) d t
\end{gathered}
$$




$$
\beta=\tan ^{-1}\left(\frac{F_{I}}{F_{R}}\right)
$$

ここで, $F_{R}$ は振動変位に比例する空力剛性， $F_{I}$ は振動速 度に比例する空力減衰, $\beta$ は非定常空気力と振動変位と の位相差を表す。本研究では, 得られた変位比例成分 $F_{R}$ 之速度比例成分 $F_{I}$ を速度圧 $q_{H}$ と単位幅 $B_{\mathrm{u}}(=1)$ における荷 重負担面積 $A_{S}\left(=B_{\mathrm{u}} L\right)$, 振幅 $z_{0}$ およびスパン $L$ を用いて無 次元化し, 次式で定義される空力剛性係数 $a_{K}$ と空力減衰 係数 $a_{C}$ として表す。

$$
\begin{gathered}
a_{K}=\frac{F_{R}}{q_{H} A_{S}\left(z_{0} / L\right)} \\
a_{C}=\frac{F_{I}}{q_{H} A_{S}\left(z_{0} / L\right)}
\end{gathered}
$$

一般化風力 $F_{j}$ を用いた屋根全体に作用する非定常空気

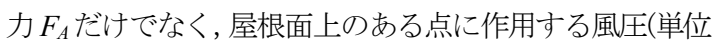
面積当たりの風力)基づく非定常空気力にも着目寸る。 いま, 加振振動数 $f_{\mathrm{m}}$ で強制的に振動されている屋根の位 置 $s$ での振動に対する変位比例成分(空力岡性) $F_{R P}$ と速度 比例成分(空力減衰) $F_{I P}$ は次式のように表される。

$$
\begin{gathered}
F_{R P}=\frac{1}{T} \int_{-T}^{T} F_{r}(s, t) \frac{z(s, t)}{z_{0}} d t \\
F_{I P}=\frac{1}{T} \int_{-T}^{T} F_{r}(s, t) \frac{\dot{z}(s, t)}{\dot{z}_{0}} d t \\
\beta_{P}=\tan ^{-1}\left(\frac{F_{I P}}{F_{R P}}\right)
\end{gathered}
$$

ここで, $F_{r}(s, t)$ は屋根の位置 $s$ に作用する風力 $\left(=P_{\mathrm{e}} B_{\mathrm{u}} d s\right)$, $\dot{z}_{0}$ は振動の腹の位置における速度, $\beta_{\mathrm{p}}$ は測定位置 $s$ での 非定常空気力と振動変位との位相差を表す。屋根全体に 作用する非定常空気力と同様, $F_{R P}$ と $F_{I P}$ を無次元化し, 次式のように空力剛性係数 $a_{K P}$ と空力減衰係数 $a_{C P}$ として 表す。

$$
\begin{aligned}
& a_{K P}=\frac{F_{R P}}{q_{H} A_{S P}\left(z_{0} / L\right)} \\
& a_{C P}=\frac{F_{I P}}{q_{H} A_{S P}\left(z_{0} / L\right)}
\end{aligned}
$$

ここで, $A_{S P}$ は位置 $s$ における荷重負担面積 $\left(B_{\mathrm{u}} d s\right)$ を表す。

3.2 位置による非定常空気力特性

屋根の位置による非定常空気力特性に着目するために, 式(18)，(19)を用いて，逆対称一次モードの 2 つの腹の位 置 $\left(s / s_{\text {max }}=0.25,0.75\right)$ に対する非定常空気力特性を評価す る。図 7 に一様流と境界層乱流中で得られた陸屋根にお ける空力剛性係数 $a_{K P}$, 空力減衰係数 $a_{C P}$, 位相差 $\beta_{\mathrm{P}}$ 示 す。横軸は無次元風速 $U_{\mathrm{H}}{ }^{*}\left(=U_{\mathrm{H}} /\left(f_{\mathrm{m}} L\right)\right)$ を表す。比較のため
に, 図には大熊ら 7)の結果(一様乱流 : 乱れ強さ $7 \%$ )もプ ロットされている。加振振幅 $z_{0}$ の大きさによって屋根に 作用する非定常空気力の大きさは変化するが, 式(15), (16) のように無次元振幅 $z^{*}\left(=z_{0} / L\right)$ を用いることで, 大熊らの風 洞実験 ${ }^{7)}$ および本研究の CFD 解析における様々な加振振 幅に対する結果は加振振幅に依存しないものとなる。本 研究における数值流体解析では一様流と境界層乱流を用 いているため，大熊らの風洞実験結果と気流そのものは 異なるが，全体的な傾向はよく対応している。 $a_{K P}$ と $a_{C P}$ の定性的な傾向に着目すると， $U_{\mathrm{H}}{ }^{*}$ が増加するにつれて， $a_{K P}$ およ゙ $a_{\mathrm{CP}}$ の絶対值は減少している。また, $U_{H}{ }^{*}$ が大き い場合, $U_{H}{ }^{*}$ の増加に伴う $a_{K P}, a_{C P}$ の変化率は徐々に小さ

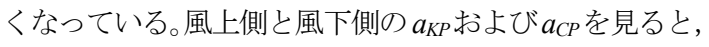
$U_{H}{ }^{*}=0.5 \sim 1.5$ の範囲で傾きが変化している。特に, 風上 側と風下側における $a_{C P}$ に着目寸ると, $U_{\mathrm{H}}{ }^{*}=1.0$ 付近では 風上側では $a_{C P}>0$ (負減衰) となっているが，風下側では $a_{C P}<0$ (正減衰)となっており, 屋根の風上側と風下側で空 力減衰力の作用方向が異なっている。ここで, 気流と剥離 泡の大きさの関係を検討するために非振動屋根の屋根ま わりの流れ場に着目寸る。図 8 に一様流と境界層乱流中 の平均風速ベクトルの $x$ 方向成分の分布を示す。この図 によると, 再付着位置は一様流で $s / s_{\max } \approx 0.5$, 境界層乱流 で $s / s_{\max } \approx 0.2$ である。境界層乱流では, 再付着位置と最大 振幅をもたらす位置が比較的近いことから, 剥離泡内で 発生する負圧と屋根の振動による相互作用が非定常空気 力に影響を及ぼすものと考えられる。この点については, 今後，スパンの異なる屋根で更なる検討が必要である。

変位に対する非定常空気力の位相差 $\beta_{P}$ に着目寸ると, 風上側では $U_{\mathrm{H}}{ }^{*}$ の増加に伴って $\beta_{P}$ は徐々に増大寸る。一 方, 境界層乱流では, 一様流での風上側と同様, $U_{\mathrm{H}}{ }^{*}$ の増 加に伴って $\beta_{P}$ は徐々に増大寸るが，風下側ではそのよう な傾向は見られない。このような傾向は既往の一様乱流 中での風洞実験 7でも見られた。 $\beta_{P}=90^{\circ}$ のとき，屋根に は非定常空気力によって共振的な現象が生じると考えら れる7。風上側の值に着目すると, 一様流では $U_{\mathrm{H}}{ }^{*}=1.0$ 付 近で $90^{\circ}$ となっているのに対して, 境界層乱流で同様な現 象が発生するのは $3<U_{\mathrm{H}}{ }^{*}<4$ の範囲である。風下側の結 果によれば, 一様流では $U_{\mathrm{H}}{ }^{*}=2$ 付近で位相差が $90^{\circ}$ を超 えると考えられるが, 境界層乱流では, そのような傾向は 見られない。既往の研究》では,「屋根の振動に負減衰的 効果を与える風力は屋根の振動によって新たな渦が風上 端部から発生したものではなく, 剥離泡内で形成される 渦が振動の刺激を受けることによって発生する」として いる。本研究の結果はそれに加えて, ある無次元風速で 


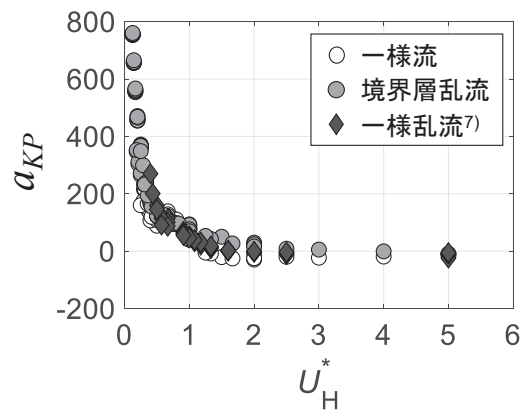

（a）空力岡性係数，風上側

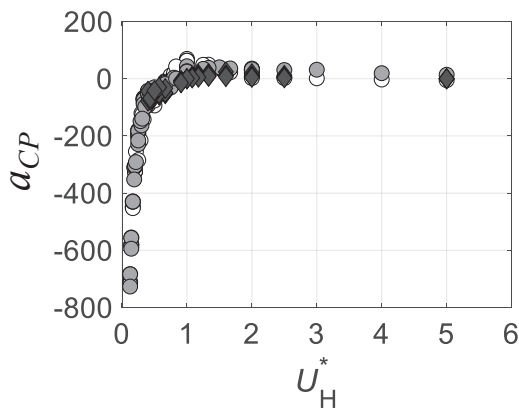

(c) 空力減衰係数, 風上側

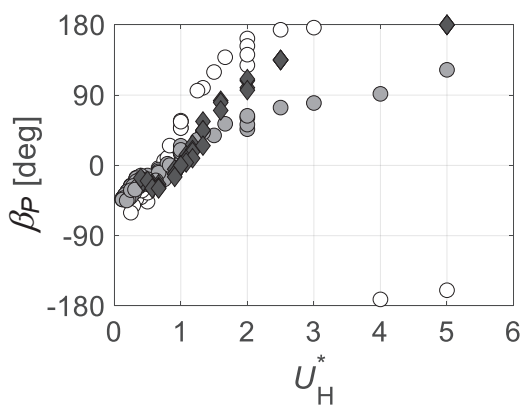

(e) 位相差, 風上側

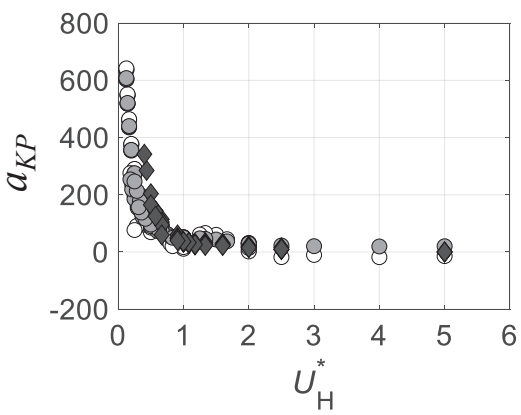

（b）空力剛性係数, 風下側

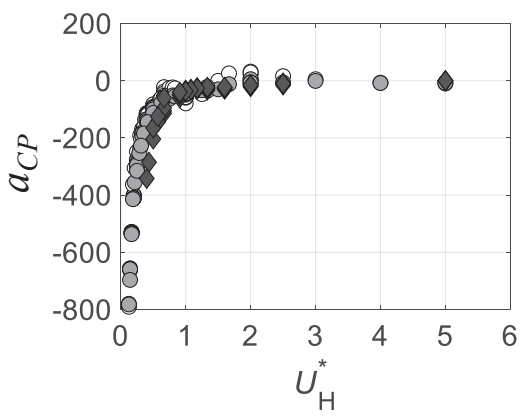

(d) 空力減衰係数, 風下側

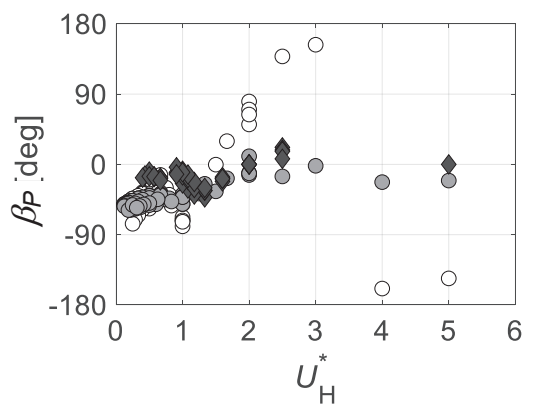

(f) 位相差, 風下側

図 7 振動モードの腹の位置における非定常空気力の特性(陸屋根)

Fig. 7 Characteristics of unsteady aerodynamic forces at anti-nodes of vibration mode (Flat roof)

は，再付着点近傍の風下位置まで負減衰効果を与える風 力が発生していることを示している。

同様に，円弧屋根 $(r / L=0.1,0.2)$ と吊屋根 $(d / L=0.05,0.1)$ に 対して, 境界層乱流中での $s / s_{\max }=0.25,0.75$ における非定 常空気力特性を図 9 に示す。全体的な傾向は陸屋根と同 様であり, $U_{\mathrm{H}}{ }^{*}$ が小さい範囲 $\left(U_{\mathrm{H}}{ }^{*}<1.0\right)$ ではいずれの屋根形 状についてもほぼ同様な結果が得られている。 $a_{K P}$ に着目 すると, 陸屋根の傾向は吊屋根と類似しているが, 円弧屋 根ではそれらとは異なり, 常に $a_{K P}>0$ である。 $a_{C P}$ に着目 すると, 吊屋根については, $0.5<U_{\mathrm{H}}{ }^{*}<1.5$ の範囲におけ る変化が他の屋根形状とは異なり緩やかである。これは, 吊屋根では風上端部での流れの剥離によって生じた剥離

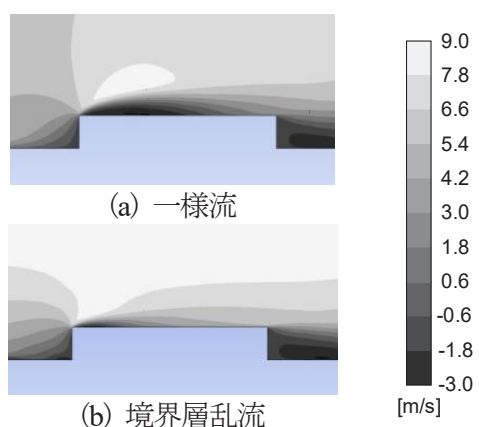

図 8 平均風速ベクトルの $x$ 方向成分

Fig. 8 Distribution of the $x$-components of mean wind velocity vectors 
泡が大きく, 定常的な逆流が存在し, 屋根まわりの流れ場 が陸屋根や円弧屋根の場合とは大きく異なるためと考え られる。

位相差 $\beta_{P}$ の変化に着目寸ると, 円弧屋根については, 屋根面に沿った流れが支配的になるため, 傾向は陸屋根 や吊屋根とは大きく異なり, $U_{\mathrm{H}}{ }^{*}>2$ の時, $\beta_{P}$ はほぼ 0 と なっている。これは, 非定常空気力が変位に同期して作用 していることを表している。一方, 吊屋根では陸屋根と同 様, 風上側と風下側の変化の傾向が異なっており, $\beta_{P}$ は 風上側では $U_{\mathrm{H}}{ }^{*}$ の増加に伴って増大寸るが，風下側では $d / L=0.05$ の場合 $U_{\mathrm{H}}{ }^{*}>2.5$ で増大し, $d / L=0.1$ の場合, $U_{\mathrm{H}}{ }^{*}=5$ で減少している。

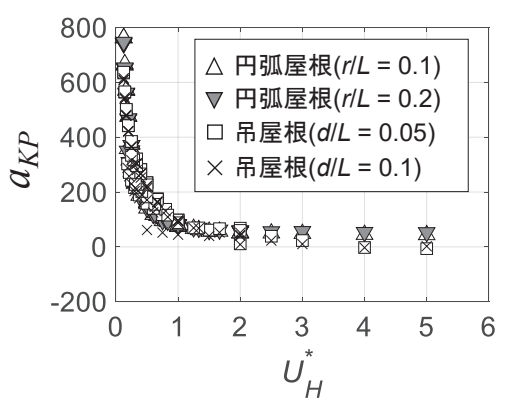

（a）空力剛性係数，風上側

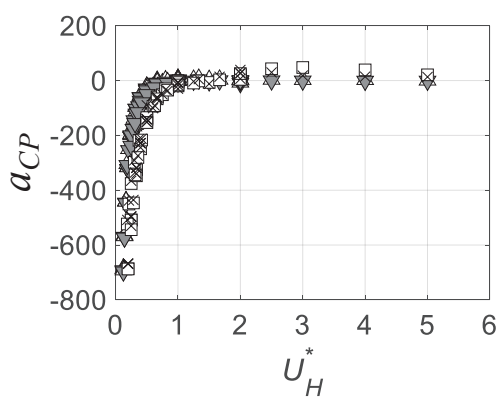

(c) 空力減衰係数, 風上側

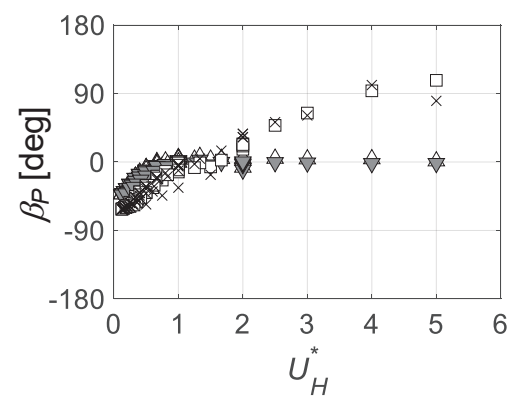

(e) 位相差，風上側
以上の結果より, 非定常空気力による空力不安定振動 は風上端部での流れの剥離に伴って生じる渦が負減衰効 果をもたらす結果と考えられる。しかし, 害際の空力不安 定振動を論じるには屋根全体の振動に着目する必要があ ることから, 3.3 節ではモーダル風力による非定常空気力 係数の評価を行う。

\section{3 屋根全体に作用寸る非定常空気力特性}

図 10 は, 境界層乱流中において屋根全体に作用寸る非 定常空気力の特性を示す。この図には本研究で検討して いる 5 種類の屋根形状に加えて既往の風洞実験(大熊ら 7), Ding and Uematsu') $\left.{ }^{9}\right)$ 結果も比較のためプロットしている。 既往の研究 9), 14)でも示されているが，位置による非定常

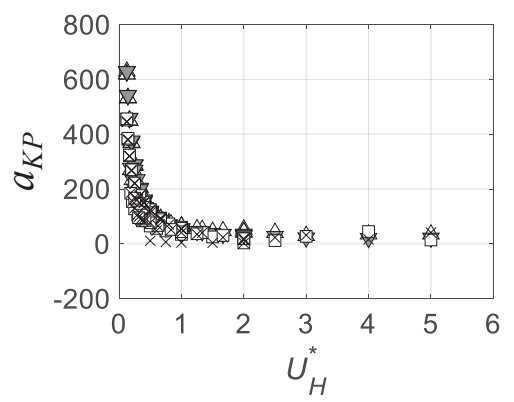

（b）空力剛性係数, 風下側

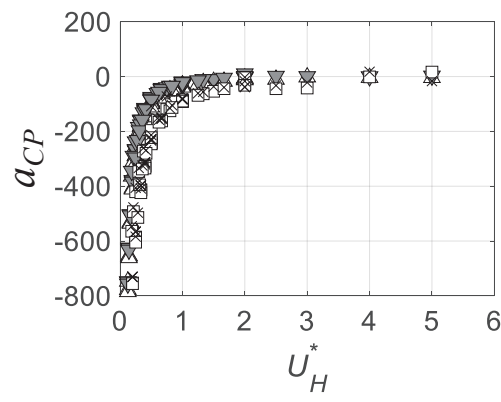

(d) 空力減衰係数, 風下側

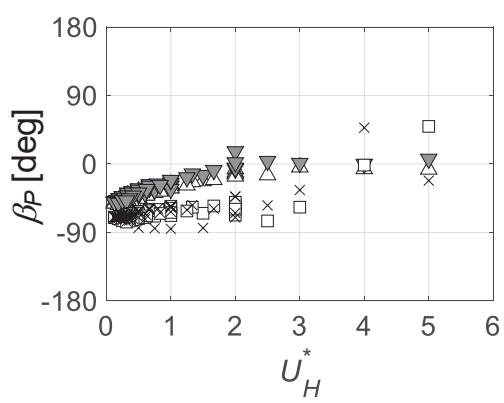

(f) 位相差, 風下側

図 9 振動モードの腹の位置における非定常空気力の特性 (円弧屋根, 吊屋根)

Fig. 9 Characteristics of the unsteady aerodynamic forces at anti-nodes of vibration mode (cylindrical and suspended roofs) 


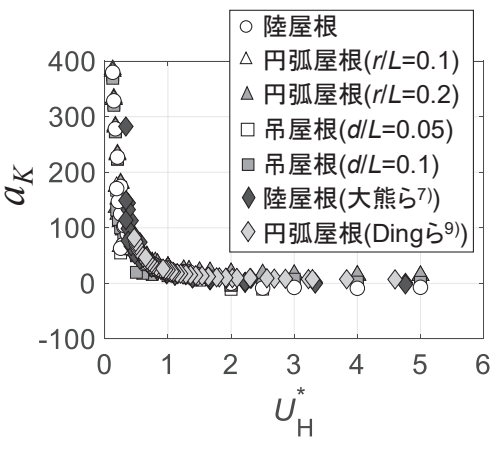

(a) 空力剛性係数(一様流)

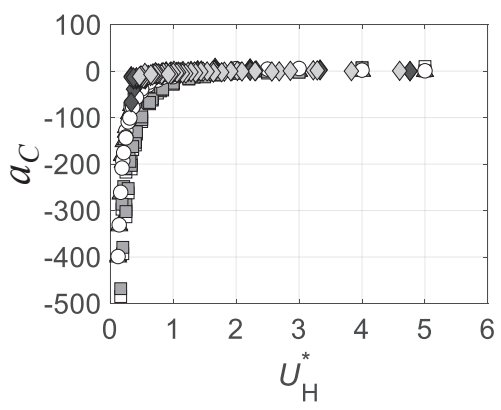

(c) 空力減衰係数 (一様流)

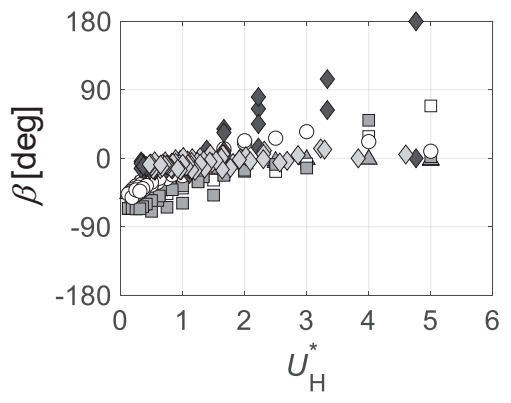

(e) 位相差(一様流)

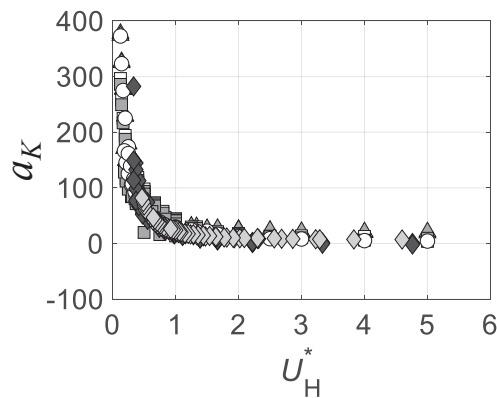

(b) 空力剛性係数(境界層乱流)

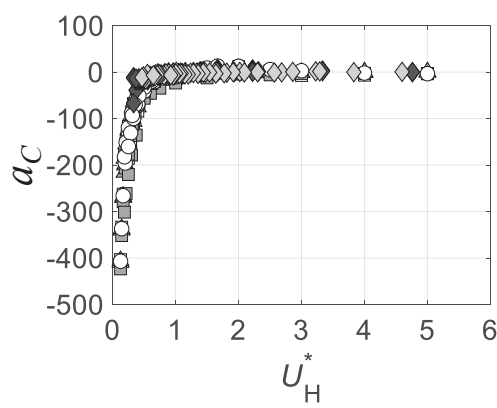

(d) 空力減衰係数(境界層乱流)

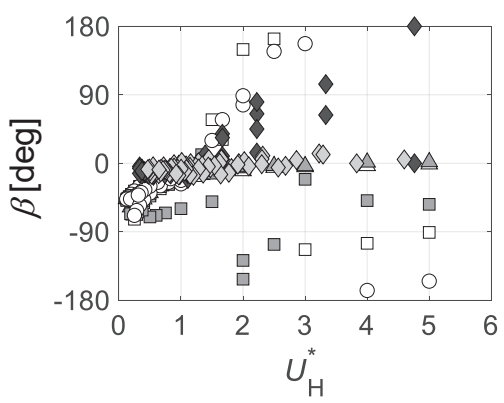

(f) 位相差(境界層乱流)

図 10 モーダル風力に基づく非定常空気力の特性

Fig. 10 Characteristics of the unsteady aerodynamic coefficients for modal wind force

空気力特性と同様，式(20)，(21)を用いて空力剛性係数 $a_{K}$ および空力減衰係数 $a_{C}$ を表すことで，これらの值は加振 振幅 $z_{0}$ によらない值となる。

いずれの結果についても, 用いた気流によらず, 既往の 風洞実験結果とよく対応しており, $U_{\mathrm{H}}{ }^{*}$ の増加に伴い， $a_{K}$ と $a_{C}$ の絶対值は徐々に減少している。 $\mathrm{Li} ら^{10)}$ によると, 陸屋根と円弧屋根ではほぼ同様な非定常空気力が得られ るとされており, 本研究でもその傾向は同様である。吊屋 根でも同様の挙動を示すが，結果のばらつきが他の屋根 形状より大きい。これは, 風上端部の流れの剥離と屋根面
での流れの滞留によって屋根まわりの流れ場が複雑にな ることが原因と考えられる。

モーダル風力の位相差 $\beta$ に着目すると, $U_{\mathrm{H}}{ }^{*}$ が増加する につれて $\beta$ は徐々に増加している。円弧屋根では, 前節に 示した $s / s_{\max }=0.25$ および 0.75 における傾向とほぼ同様で あるが，陸屋根および吊屋根では気流によって傾向が異 なっている。 $\beta>0^{\circ}$ の時, 屋根の変位に対して非定常空気 力の位相が進んでいることを示し,$\beta=90^{\circ}$ で位相差が最大 となるが, 一様流の場合, 陸屋根と吊屋根において $U_{\mathrm{H}}{ }^{*}=2.0$ 付近で $\beta=90^{\circ}$ となっている。しかし, 境界層乱流 


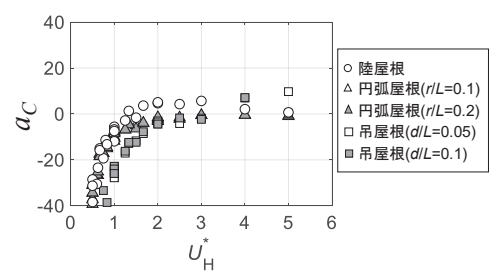

(a) 空力減衰係数(境界層乱流)

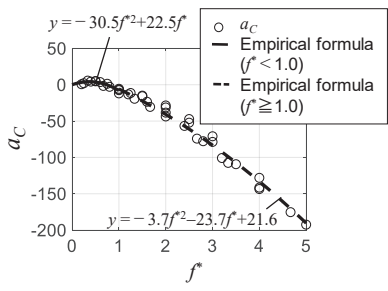

(b) 曲線近似

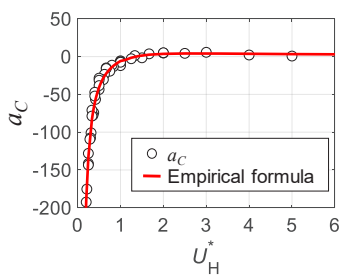

(c) 空力減衰係数と近似曲線

図 11 空力減衰係数の無次元風速あるいは無次元周波数数による変化

Fig. 11 Variation of aerodynamic damping coefficient with non-dimensional velocity or frequency

では, $U_{\mathrm{H}}{ }^{*}$ の増大に伴う $\beta$ の増加は緩やかであり，一様流 のように $\beta=90^{\circ}$ となる $U_{\mathrm{H}}{ }^{*}$ は今回の検討範囲では見られな い。したがって, 境界層乱流では一様流に比べて空力不安 定振動が発生しにくいと考えられる。一方で, $0^{\circ}<\beta<180^{\circ}$ となる領域においては $a_{C}>0$ となり, 空力負減衰効果が 生じることから，境界層乱流においても不安定振動が励 起される可能性がある。そこで次節では, 陸屋根, 円弧屋 根, 吊屋根のそれぞれの形状に対して空力安定性を包括 的に検討し, 空力不安定振動の発生条件を明らかにする。

\section{4. 質量減衰パラメータを用いた空力安定性の評価}

\section{1 空力安定性の評価方法}

大スパン屋根の空力安定性を評価するために，大スパ ン屋根の構造減衰よりも空力負減衰の効果が上回った場 合に空力不安定振動が発生すると仮定し, 大スパン屋根 の空力不安定振動の発生条件を示寸。屋根の振動系の空 力減衰 $F_{I}$ が構造減衰を上回る条件は次式で表される。

$$
\begin{gathered}
F_{I}>C_{S} \dot{z}_{0} \\
F_{I}=\left(\frac{1}{2} \rho_{a} U_{H}^{2}\right) A_{S}\left(z_{0} / L\right) a_{C} \\
C_{S} \dot{z}_{0}=2 h_{S} M_{S} \omega\left(\omega z_{0}\right)
\end{gathered}
$$

ここで, $\rho_{a}$ は空気密度, $\dot{z}_{0}$ は屋根の振動速度の片振幅, $h_{S}$ は構造減衰定数, $\omega$ は角振動数を表す。なお, 式(23)の $a_{\mathrm{C}}$ は各屋根形状に対する空力減衰係数である。屋根の空力 減衰 $F_{I}$ を得るためには, 任意の無次元風速 $U_{\mathrm{H}}{ }^{*}$ に対する $a_{C}$ を求める必要がある。そこで, 図 11 のように離散的な $U_{\mathrm{H}}{ }^{*}$ に対して得られた $a_{C}$ を近似曲線を用いて表し，任意 の $U_{\mathrm{H}}{ }^{*}$ に対する $a_{C}$ を得る。図11(a)は，各屋根形状に対す る空力減衰係数を無次元風速 $U_{\mathrm{H}}{ }^{*}$ に対してプロットした

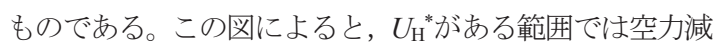
衰係数 $a_{C}$ が 0 より大きくなる空力負減衰領域が見られる。 次に, 代表例として陸屋根の結果に着目し, 空力減衰係数 $a_{\mathrm{C}}$ 無次元周波数 $f^{*}\left(=U_{\mathrm{H}} / f_{m} L\right)$ の関数として表す(図 11(b))。 ここで得られたプロットを $f^{*}<1$ と $f^{*} \geqq 1$ の範囲に分ける
と，それぞれ $f^{*} の 2$ 次関数で近似することができる。その 結果に対して，横軸に無次元風速 $U_{\mathrm{H}}{ }^{*}$ を取ると図 11(c)の ようになる。これによって，任意の $U_{\mathrm{H}}{ }^{*}$ 対して $a_{C}$ を求 めることができる。

式(22)に式(23)，(24)を代入することで, 空力不安定振動 が発生する無次元風速 $U_{\mathrm{H}}{ }^{*}$ は質量減衰パラメータ $\delta_{R}$ を用 いて次式のように求められる。

$$
\begin{gathered}
\delta_{R}<\frac{1}{16 \pi^{2}} a_{C} U_{H}^{*_{2}} \\
\delta_{R}=\frac{h_{S} M_{S}}{\rho_{a} A_{S} L}
\end{gathered}
$$

式(25)は空力負減衰が構造減衰を上回る条件式であり, 式 (26)の質量減衰パラメータ $\delta_{R} よ り も$ 右辺の值が大きけれ ば系全体の減衰力が負となり振動が増大寸るため, 空力 不安定振動が発生する。

\section{2 空力不安定振動の発生条件}

図 12 に式(25)で与えられる質量減衰パラメータ $\delta_{R}$ と発 現風速の関係を示す。図の曲線よりも $\delta_{\mathrm{R}}$ の值が小さい領 域が空力不安定振動の発生領域となる。ここで, 代表的な 大スパン屋根を想定し, 屋根のスパン $L$ を $120 \mathrm{~m}$, 屋根の 幅 $B$ を $80 \mathrm{~m}$, 屋根の単位面積あたりの質量 $\rho_{\mathrm{s}}$ を $2 \mathrm{~kg} / \mathrm{m}^{2}$ と仮定すると, 一般化質量 $M_{\mathrm{S}}$ は $120 \mathrm{~kg}$ となる。さらに, 構造減衰定数 $h_{S}$ を $1 \%$, 空気密度 $\rho_{a}$ を $1.2 \mathrm{~kg} / \mathrm{m}^{3}$ と仮定す ると, 質量減衰パラメータ $\delta_{R}$ は $6.9 \times 10^{-5}$ となる。この時 に得られる発現風速の值を表 2 に示す。

これらの結果によると, 屋根形状については, 円弧屋根 は他の屋根形状と比べて空力的に安定である。気流につ いては，境界層乱流の方が空力不安定振動は発生しにく い。また, 今回得られた一様流に対する結果は, 既往の空 力弾性模型による風洞実験 2) より示された空力不安定振 動の発生条件 $\left(U_{H}^{*}>1.1\right)$ に近い結果となった。

5.まとめ

本研究では, 3 種類の形状を有する大スパン屋根に対し 


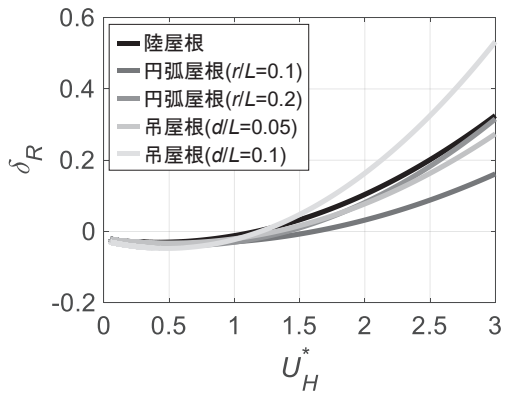

(a) 一様流

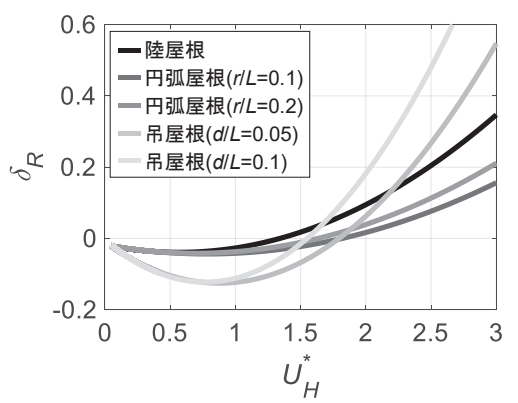

(b) 境界層乱流

図 12 質量減衰パラメータと無次元風速

Fig. 12. Mass damping parameter versus critical wind velocity

表 2 空力不安定振動の発現風速 $\left(\delta_{R}=6.9 \times 10^{-5}\right)$

Table. 2 Critical wind velocities for aerodynamically unstable vibration $\left(\delta_{R}=6.9 \times 10^{-5}\right)$

\begin{tabular}{lll}
\hline 屋根形状 & 一様流 & 境界層乱流 \\
\hline 陸屋根 & 1.16 & 1.34 \\
\hline 円弧屋根 $(r / L=0.1)$ & 1.61 & 1.82 \\
\hline 弧屋根 $(r / L=0.2)$ & 1.40 & 1.63 \\
\hline 吊屋根 $(d / L=0.05)$ & 1.32 & 1.80 \\
\hline 吊屋根 $(d / L=0.1)$ & 1.20 & 1.55 \\
\hline
\end{tabular}

て強制加振法に基づく数值流体解析を行うことで, 屋根 の空力安定性の評価を行った。得られた主な知見を以下 に示寸。

1. 屋根に作用する非定常空気力は風上側と風下側でそ の特性が異なる。風上側では空力負減衰効果をもたら 寸剥離渦が生成されるが, 風下側に移流寸るとともに, その負減衰的な影響は小さくなる。また, 一様流と境 界層乱流でその結果が異なることから, 空力不安定振 動は風上端部で生成される剥離泡の大きさに起因寸 るものと考えられる。

2. モーダル風力を用いて得られる非定常空気力に着目 すると, 円弧屋根の場合には風速増加に伴って非定常 空気力の位相差の絶対值が小さくなり, 0 に近い值を とるため, 空力不安定振動は励起されにくい。
3. 構造減衰と空力減衰の関係を用いることで, 質量減衰 パラメータを用いた屋根の空力不安定振動の発生条 件を示した。一般的な大空間屋根の場合, 屋根の空力 不安定振動は, 乱れの小さい一様流の方が境界層乱流 よりも発生しや寸い。空力不安定振動の発生風速に関 して, 陸屋根については既往の自由振動実験に近い值 を示した。

\section{謝辞}

本研究は JSPS 科研費 16J01789 および平成 28 年度公益 財団法人能村膜構造技術振興財団の助成を受けたもので ある。ここに記して謝意を表する。

参考文献

1) Uematsu, Y., and Uchiyama, K., "Wind-induced dynamic behavior of suspended roofs", Technology Reports, Tohoku University, Vol. 47, No. 2, pp. 243 - 261, (1982)

2) 松本 武雄, 「一様流中の一方向吊屋根の自励振動に ついて風洞実験」, 日本建築学会構造系論文報告集, 第384 号, pp. 90-96, (1988)

3）三宅昭春, 吉村健,「吊屋根の空力弾性振動に関する 基礎的研究 第 2 報 渦放出と励振発生の関係につい て」, 日本建築学会構造系論文報告集, 第 438 号, pp. 39-48, (1992)

4) Daw, D., J., Davenport, A., G., "Aerodynamic damping and stiffness of a semi-circular roof in turbulent wind", Journal of Wind Engineering and Industrial Aerodynamics, Vol. 32, No. 1-2, pp. 83 - 92, (1989)

5) 大熊武司, 丸川比左夫, 風間弘晴, 新堀喜則, 加藤 信男,「大スパン構造物の屋根面に作用する風圧力の 性質に関する基礎的研究」, 第 9 回風工学シンポジウ ム論文集，pp. 97-102，(1986）

6) 大熊武司, 丸川比左夫, 萩澤毅, 「大スパン構造物の 屋根面に作用する非定常風圧特性」, 第 10 回風工学 シンポジウム論文集，pp.73-78，(1988)

7) 大熊武司, 丸川比左夫, 「大スパン屋根の空力不安定 振動の発生機構について」, 日本風工学会誌, 第 42 号, pp. 35-42, (1990)

8) 杉山貞人, 田村哲郎,「大スパン構造物の空力不安定 振動に関する数值的考察, 第 16 回風工学シンポジ ウム論文集, pp. 243-248, (2000)

9) Ding, W., Uematsu, Y., "Large eddy simulation of unsteady aerodynamic behavior of long-span vaulted roofs", Journal of Zhejiang University-SCIENCE A, Vol. 18, No. 10, pp. 
$793-806,(2017)$

10) T., Li, Q., Yang, T., Ishihara, "Unsteady aerodynamic characteristics of long-span roofs under forced excitation", Journal of Wind Engineering and Industrial Aerodynamics, Vol. 181,pp. 46-60, (2018)

11）植松康，曽根孝行，野口満美，「日本における空間構 造の形状・構造特性と而風設計法」, 日本風工学会論 文集，第96 号，pp. 107-116, (2003)

12) F., Nicoud, and F., Ducros, "Subgrid-Scale Stress Modelling Based on the Square of the Velocity Gradient Tensor", Flow, turbulence and Combustion, Vol. 62, No. 3, pp. $183-200,(1999)$

13）高舘祐貴, 植松康,「一様流中における大スパン構造
物の屋根面に作用する風圧の特性」, 日本建築学会東 北支部研究報告集 構造系, 第 81 号, pp. 121-124, (2018)

14）高舘祐貴, 植松康,「大スパン陸屋根に作用する非定 常空気力と空力安定性」, 第 25 回風工学シンポジウ 么論文集，pp. 265-270,(2018)

15) Takadate, Y., Uematsu, Y., "Steady and unsteady aerodynamic forces on a long-span membrane structure", Journal of Wind Engineering and Industrial Aerodynamics, Vol. 193, 103946, (2019)

16) ANSYS Fluent ユーザーズガイド(Ver. 17.0), (2016)

17）日本建築学会 : 建築物荷重指針・同解説，(2015） 